\title{
Cable-Tie Seton for Treatment of Complex Fistula in Ano
}

\author{
MOSTAFA M. SALAMA, M.D. and AHMED ABD EL AL SULTAN, M.D. \\ The Department of General Surgery, Faculty of Medicine, Al-Azhar University
}

\begin{abstract}
Background: Seton is defined as a string-like material that can be tied through the fistula to induce an inflammatory reaction leading to fibrosis that fixes the sphincter and prevents its retraction when it is divided. Seton is commonly used by surgeons for treatment of complex anal fistula (complexity means: Fistula crossing $>30 \%$ to $50 \%$ of the external anal sphincter, recurrence, multiple tracks, or co-existence of anal incontinence).
\end{abstract}

Aim of Study: To detect the anal incontinence and recurrence rate when we treat patients suffering from complex anal fistula by cable tie seton at a university hospital.

Patients and Methods: Our study is a prospective case series including patients with complex anal fistula i.e. recurrent fistula, managed with cable tie seton from May 2015 to July 2018. Patients were followed up in the outpatient clinic after one week of seton insertion and then every two week. At each visit time, the cable-tie was tightened enough if found loose without anesthesia. Incontinence was inquired about using wexner's score.

Results: During the study period, Seventy nine patients were treated. Their age was (mean \pm standard deviation) $41 \pm 10.6$ years. Tightening of the seton was done with a median of six times (3-15 times range). All patients had complete healing in 11.2 \pm 5.7 weeks. Follow-up was done for all patients for a variable period with minimum of one year and none of the them had any anal incontinence. Recurrence was noticed in $4(5 \%)$ patients.

Conclusion: The cable tie seton proved to be safe for the patients, cost effective and had low morbidity when used for the treatment of complex fistulae in-ano. Therefore, it can be recommended as standard method for treating complex fistulaein-ano.

Key Words: Seton - Fistula in ano-Recurrence.

\section{Introduction}

FISTULA-IN-ANO is a commonly encountered surgical problem. Its prevalence is 1.2 to $2.8 / 10,000$ [1]. According to Parks et al., the classification of fistula-in-ano, is based on the relation of location of its tract to anal sphincter muscle: Intersphincteric,

Correspondence to: Dr. Mostafa M. Salama,

E-Mail: mostafa slama2015@yahoo.com trans-sphincteric, suprasphincteric, or extrasphincteric [2]. Most consider the term complex fistula as a modification of the Park's classification, which may fall in any one of the following situations: If the track crosses $>30 \%$ to $50 \%$ of the external sphincter, anterior fistula in females, multiple branched fistula tracks, recurrent fistula, or the patient complain of preexisting incontinence, history of local irradiation, or Crohn's disease. Due to the fact that the anal sphincter must be included in complex fistula, the treatment can increase the risk of impairment of continence [3,4]. There is no agreement on single technique for the treatment of fistula-in-ano, thus, treatment option must be chosen according to surgeon's judgment and experience. The surgeon must keep in mind the problem of sphincter division, and the relation of its extent to postoperative healing rate, and degree of functional loss [3]. Regardless fistula type and extent, the principles of surgery for anal fistula are to get rid of it, prevent recurrence for long time after surgery, and preserve most sphincter function. Most conventional treatment for fistula in ano were fistulotomy and fistulectomy, that had been proven to be effective [5]. Surprisingly, seton have been used to treat anal fistula hundreds of years ago; however, in the literature, the only indications are high or complex fistula in ano with the hope that fecal incontinence and recurrence are minimal [6] Seton is defined as a string-like material that can be tied through the fistula to induce an inflammatory reaction leading to fibrosis that fixes the sphincter and prevents its retraction when it is divided. By doing this, it preserves sphincter continuity during cutting process [7].

For the mentioned purpose, plenty of material types are in use for slow cutting. Silastic tube, silk, braided silk were firstly used but rubber band, braided polyester were used later. Now, vascular loop, polypropylene and cable tie are mor commonly used [7]. The reported incontinence rate is 
$0 \%$ to $62 \%$ [7] and recurrence rate ranges from $0 \%$ to $16 \%$ [8] with different material types used as seton. Many surgeons prefer cable tie as it is very cheap, very available in addition to easy insertion, and convenient tightening which can be done in a clinic setting without need of analgesia, even by the attendants if trained well. We have conducted this trial with a larger sample size participating in it to define the incontinence and recurrence rate of this type seton along with risk factors associated with recurrence at a tertiary care hospital.

\section{Patients and Methods}

This study was conducted on patients with complex anal fistula including recurrent fistula or those encircling big portion of external anal sphincter, who were managed with cable tie seton from May 2015 to July 2018. Patients with preoperative incontinence, inflammatory bowel disease like crohn's disease, anorectal cancer, intestinal tuberculosis or American society of anaesthesiologists (ASA) IV were excluded. When patients were seen in the clinic, no effort was made to define the tract or investigate the condition radiologically. They were counseled about and gave a consent for the method of dealing with the fistula and informed that healing and convalescence will be prolonged.

All patients were operated as day-care cases, except ASA-III patients (operated as regular inpatients). Only clear-liquid diet was taken for 24 hours prior to surgery for cleaning bowel and a clean enema was added. Most patients preferred general anesthesia, but spinal anaesthesia and caudal blocks were used at times. In the operation room, we evaluated the patients in the lithotomy position. A proctoscope was used and a roll gauze was manipulated inside the anal/rectal canal. Methylene blue was used to stain the entire tract by injecting it through the external opening using a syring connected to sheath of a cannula put into external opening. The roll of gauze was withdrawn gradually to identify the depth and position (circumferential) of internal opening. The external opening was smoothly probed using a standard $3 \mathrm{~mm}$ blunt-tipped probe until it reached the internal opening.

The amount of muscle superficial to the probe was evaluated. We then attached 9- to 11 - inch length of intravenous tubing to the probe and drawn through the tract from the external opening to the internal opening. The tissue around the external opening was then dissected around the tract (having the drip set tube inside it) up to the sphincter. The core of dissected tissues was then excised out of the tubing. The whole length of skin from the external opening up to the most lateral portion of the tract was deeply incised to give direct contact between the cable tie seton (Fig. 1) and the sphincter; the cable tie was then inserted into the drip set tubing from outside inwards, and the drip set tubing was pulled out from the anal side of the opening.

Then, the cable tie was locked and tightened to allow it to sit loosely over the sphincter (became within the loop of seton). The wound was covered using dry gauze dressing and held in place using a sanitary napkin and waist thong. Analgesia was provided using paracetamol and if not effective, NSAID's (diclofenac) were used. Care at home consisted of hot soaks and (Sitz bath)/hot sprays or washes then covering by dry gauze which is retained by fitting undergarments. Patients were seen in the outpatient clinic after 72 hours to reinforce postoperative instructions and for wound evaluation. The patients were then seen every other week and encouraged to walk; at the same time, the cable tie was tightened if found loose. On each visit, fecal incontinence was questioned according to Wexner's score (Table 3) [9]

To remove the cable tie just we divided it near the knuckle if the cable tie did not completely cut through despite complete healing of lateral wound or core sphincter of a centimeter diameter was left behind. Data was analyzed with SPSS version 17. Continuous variables were analyzed as means \pm $\mathrm{SD}$, where as categorical variables were analyzed as proportions and percentages. Risk factors of recurrence were analyzed with Chi square or Fisher's exact test wherever applicable.

\section{Results}

We operated on 79 patients having fistula-inano using cable tie as a seton during the period from May 2015 to July 2018. Patients, age (mean \pm standard deviation) was $41 \pm 10.6$ years. Seventyeight patients $(98.7 \%)$ were males, and seven patients $(8.9 \%)$ were diabetic. Fifty-eight (73.4\%) patients had no prior history of perianal diseases, while the rest had a history of anal abscess (perianal or ischiorectal). Fifty-three patients $(67.1 \%)$ had no history of operations for fistula-in-ano, whereas rest had recurrent fistulae as a primary diagnosis (Table 1). Fistula tract was traced and delineated in all the cases.

The majority of patients (58.2\%) had high transsphincteric anal fistula and $70.9 \%$ had the internal opening above dentate line. The seton was tightened numerously with a median of six times (3-15 times range). Most of the patients tolerated the tightening session well but with minimal to 
mild pain, and analgesia was give, namely paracetamol $1 \mathrm{gm}$ every six hourly on as needed basis.

Complete wound healing occurred in $11.2 \pm 5.7$ weeks. All the patients were followed-up for a minimum period of one year (or till healing if the period exceeded one year), and none of the patients complained of incontinence. Recurrence occurred in $4(5 \%)$ patients. Although recurrence was found more in high transsphincteric fistulae, fistulae having internal opening above dentate line and external opening anterior to transverse midline (Table 2), these were statistically insignificant factors. One patient had unbearable discomfort and thus got the seton removed. None of the patients had any bleeding, wound infection, dislodgement, or slippage of the seton.

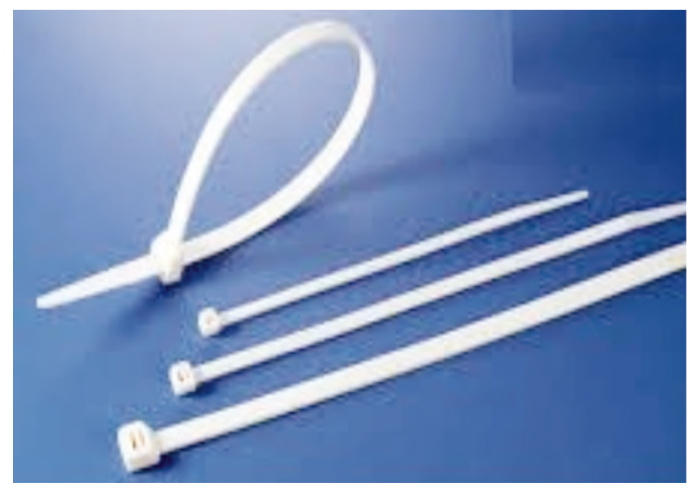

Fig. (1): Cable tie.

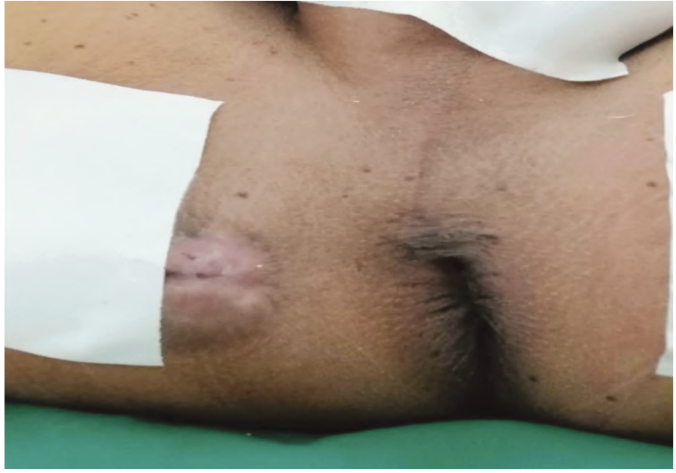

Fig. (2): External opening of a high branched perianal fistula.

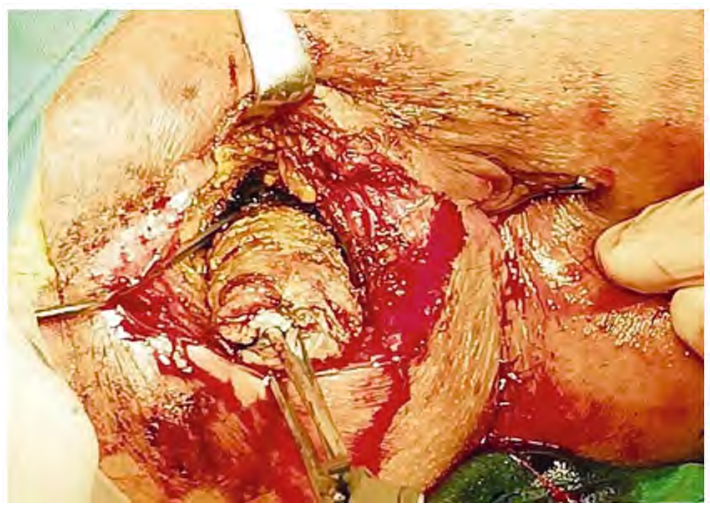

Fig. (3): The fistula track dissected.

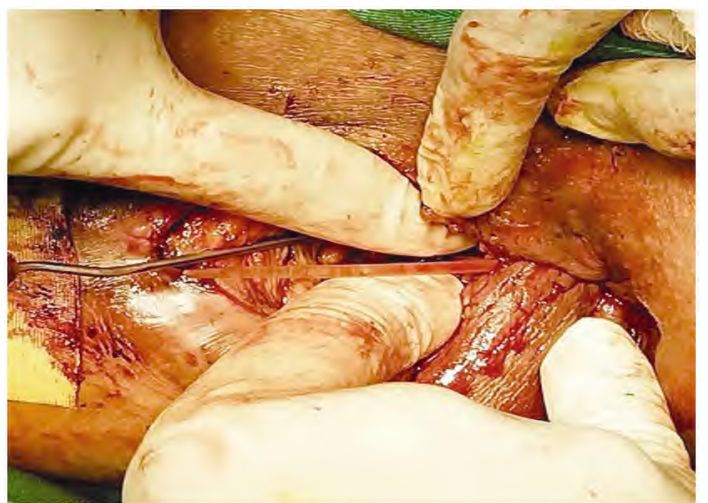

Fig. (4): Cable tie seton was tied around the anal sphincter muscle.

Table (1): Baseline variables.

\begin{tabular}{lc}
\hline Characteristics & Value \\
\hline Age & $41.3 \pm 10.6$ \\
Sex: & $78(98.7 \%)$ \\
Male & $1(1.3 \%)$ \\
$\quad$ Female & \\
Type of fistula: & $25(31.6 \%)$ \\
$\quad$ Low transsphincteric & $46(58.2 \%)$ \\
$\quad$ High transsphincteric & $08(10.1 \%)$ \\
$\quad$ Suprasphincteric & \\
Internal opening: & $23(29.1 \%)$ \\
$\quad$ At dentate line & $56(70.9 \%)$ \\
$\quad$ Above dentate line & \\
External opening from anal verge & \\
(Goodsall's rule): & \\
$\quad$ Within 2.5 cms & $24(30.4 \%)$ \\
$\quad$ Beyond 2.5 cms & $55(69.6 \%)$ \\
External opening according to & \\
goodsall's rule: & \\
$\quad$ Anterior & \\
$\quad$ Posterior & $34(55.7 \%)$ \\
Outcomes: & \\
$\quad$ Perfect continence & \\
$\quad$ Recurrence (1 year) & $04(5.1 \%)$ \\
\hline
\end{tabular}

Table (2): Risk factors for recurrence.

\begin{tabular}{llll}
\hline $\begin{array}{l}\text { Characteristics } \\
\text { value }\end{array}$ & $\begin{array}{c}\text { Recurrence } \\
(\mathrm{n}=4)\end{array}$ & $\begin{array}{c}\text { No recurrence } \\
(\mathrm{n}=75)\end{array}$ & $\begin{array}{c}p \text { - } \\
\text { value }\end{array}$ \\
\hline DM & 0 & $7(9.3 \%)$ & .685 \\
Previous surgery & $1(25 \%)$ & $25(33.3 \%)$ & .60 \\
Type of fistula: & & & \\
$\quad$ Low & 0 & $25(33.3 \%)$ & .29 \\
$\quad$ High & $3(75 \%)$ & $43(57.3 \%)$ & \\
$\quad$ Suprasphincteric & $1(25 \%)$ & $7(9.3 \%)$ & \\
$\quad$ Type of fistula: & & & \\
$\quad$ Primary & $3(75 \%)$ & $50(66.6 \%)$ & .31 \\
$\quad$ Recurrent & $1(25 \%)$ & $25(33.3 \%)$ & \\
Internal opening: & & & .16 \\
$\quad$ Below dentate line & 0 & 23 & \\
$\quad$ Above dentate line & 4 & 52 & \\
$\quad$ External opening: & & & \\
$\quad$ Anterior & 3 & 41 & \\
$\quad$ Posterior & 1 & 34 &
\end{tabular}


Table (3): Wexner's score for fecal incontinence.

\begin{tabular}{lccccc}
\hline Characteristics & Never & Rarely & $\begin{array}{c}\text { Some- } \\
\text { times }\end{array}$ & Usually & Always \\
\hline Flatus & 0 & 1 & 2 & 3 & 4 \\
Liquid stool & 0 & 1 & 2 & 3 & 4 \\
Solid stool & 0 & 1 & 2 & 3 & 4 \\
Wear pad & 0 & 1 & 2 & 3 & 4 \\
Alteratioin in & 0 & 1 & 2 & 3 & 4 \\
$\quad$ life style & & & & & \\
\hline
\end{tabular}

\section{Discussion}

The seventy nine patients treated in our study with cable-tie seton for their complex anal fistulae have a rate of $0 \%$ incontinence and $5 \%$ recurrence. The data was prospectively collected from a large number of patients. The data on continence was detected using validated Wexner's score in the patients having complete follow-up, which included not only incontinence to feces but also to flatus. However, there is no comparison group because it is a single-arm study.

Whatever the material, expertise and judgment of the surgeon are the most important factor determining rate of incontinence or recurrence (Ritchie et al., 2009). So, there are many factors that should be considered during seton selection. The ideal seton is durable, available, cheap, nonallergic, easy to tie even in clinic setting, and repeated tightening is achievable without causing much pain and without need for anesthesia (local or general) [10] .

Cable tie seems to have most of these properities. It is constructed of polyamide (nylon) and tieing it is through a selflocking system in which clicks are equally distributed, which helps the operator to tight it enough by just slipping its end without any need of further assistance. Tightening is thus gradually applied in a controlled manner. Therefore, it is so easy to tighten the seton in the clinic unlike other setons, where the patient is usually taken to the operating room repeatedly which logically add to the cost and consequences of analgesia to the patient. After tightening, all patients have pain for few minutes but none of them had unbearable pain; this is due to the controlled tightening the cable tie achieve in addition to the fact that only loose seton is to be tightened. This gradual, precise and controlled tightening reduced the incidence of anal incontinence and fistula recurrence; however, at the cost of much longer duration of treatment in which seton is in place (11.2 \pm 5.7 weeks). None of the patients complained of any difficulty in walking or carrying out daily activities.
Once engaged, the cable tie is self locking and is maintained in place by the tissues inside the loop. Abrasion/irritation caused by free movement of the opposing gluteal surfaces was prevented by a piece of gauze on either side of the free end of the cable-tie. The gauze is held in place by an undergarment. Similar results has been achieved previously when cable tie has been used. Gurer et al., [10] found no recurrence and no incontinence in the 17 patients who were treated with cable tie and they reported a mean healing time of 38.94 days and a complication rate of $12 \%$. Vatansev et al., [11] reported a rate of $0 \%$ recurrence, $15.6 \%$ incontinence, with mean duration of healing of 53 days in his series of 32 patients managed by cable tie.

Conduction of our study on large sample size (79 patients) added to the power of the results. We found $0 \%$ incontinence and low recurrence rate of $5 \%$. We did not encounter the problems of loosening in cable-tie seton (as in elastic tie) [12], cumbersome and imprecise tightening as a bunch of silk ties produces, or second procedure which may be needed draining setons. Other ways of treatment have been reported including fibrin glue, collagen plug and Ligation of Intersphincteric Fistula Tract (LIFT).

Metanalysis of trials using fibrin glue as a treatment option did not show any significant difference relative to other techniques as regard recurrence or incontinence [13]; Being too expensive make it unwise to be used in a low income country. Financially, the cost of fibrin glue equals or more than the cost of seton placement including entire day care. Studies on LIFT are also promising and may be good alternative [14]; however, learning curve is steep, and technical expertise is mandatory for good results especially for complex anal fistulae. The $0 \%$ incontinence in our patients can be explained by; (1) Delicate dissection and, therefore, no damage to the anal sphincter muscle complex (after staining the track, only the extreme lateral portion of the fistula tract was cored out and probed. The track was then "intubated" with a short length of an intravenous set tube to pass the cable tie through, (2) The sphincter complex is very gradually cut through owing to the direct compression effect of the cable-tie and "wearing through" the tissues produced by movements and walking. The depth of the tissues have enough time and chance of adhering to each other by fibrosis that has occurred. Such fibrosis fix and does not permit distraction of the sphincter muscle from each others which could result in incontinence. 
The factors participating in fistula recurrence are many and include the complexity and level of the track, the distance of the external opening from anal verge, if the horseshoe extension is found or not, failure of the surgeon to detect the internal opening at surgery. The overall experience of the operator in such complicated anorectal procedures appear to be very important [15]. In our study, we had identified the internal opening in all patients without any radiological means, and if this is correlated with the low recurrence rate, we can reach to a conclusion that the most important factor is the experience and judgment of the surgeon. Although this seems a subjective decision, it is pragmatically logic and cost effective in lowincome countries like ours. The cost of MRI alone is exceeding the cost of the entire procedure. With this cautious technique, we can achieve the best possible results without radiological aids. The literature reported, a wide range of incontinence rates after cutting seton treatment. Ritchie et al., [7] have found no relationship between incontinence and the frequency of tightening, seton type, or classification of fistula. Hence, importance of surgeon's experience cannot be denied and the use of a seton with additive qualities as stated above is very important.

\section{Conclusion:}

The cable-tie seton is safe, precise, cheap, ubiquitous, pragmatic, and a cost-effective device for the treatment of complex fistulae-in-ano. We, recommend it for treating complex fistulae-in-ano which require seton placement. It does not have the drawbacks of repeated anesthesia and visits to the operating theater. It reduces the morbidity, inconvenience to the patients.

\section{References}

1- ZANOTTI C., MARTINEZ-PUENTE C., PASCUAL I., PASCUAL M., HERREROS D. and GARC'1A-OLMO D.: "An assessment of then incidence of fistula-in-ano in four countries of the European Union," International Journal of Colorectal Disease, Vol. 22, No. 12, pp. 14591462, 2007.

2- PARKS A.G., GORDON P.H. and HARDCASTLE J.D.: "A classification of fistula in ano", British Journal of Surgery, Vol. 63, No. 1, pp. 1-12, 1976.

3- KODNER I.J., MAZOR A., SHEMESH E.I., et al.: "Endorectal advancement flap repair of rectovaginal and other complicated anorectal fistulas", Surgery, Vol. 114 No. 4, pp. 682-690, 1993.

4- MIZRAHI N., WEXNER S.D., ZMORA O., et al.: "Endorectal advancement flap: Are there predictors of failure?" Diseases of the Colon and Rectum, Vol. 45, No. 12, pp. 1616-1621, 2002.

5- SEOW-CHOEN F. and NICHOLLS R.J.: "Anal fistula", British Journal of Surgery, Vol. 79, No. 3, pp. 197-205, 1992.

6- PEARL R.K., ANDREWS J.R., ORSAY C.P., et al.: "Role of the seton in the management of anorectal fistulas", Diseases of the Colon and Rectum, Vol. 36, No. 6, pp. 573-579, 1993.

7- RITCHIE R.D., SACKIER J.M. and HODDE J.P.: "Incontinence rates after cutting seton treatment for anal fistula", Colorectal Disease, Vol. 11, No. 6, pp. 564-571, 2009.

8- VIAL M., PARÉS D., PERA M. and GRANDE L.: "Faecal incontinence after seton treatment for anal fistulae with and without surgical division of internal anal sphincter: A systematic review", Colorectal Disease, Vol. 12, No. 3, pp. 172-178, 2010.

9- VAIZEY C.J., CARAPETI E., CAHILL J.A. and KAMM M.A.: "Prospective comparison of faecal incontinence grading systems", Gut, Vol. 44, No. 1, pp. 77-80, 1999.

10- GURER A., OZLEM N., GOKAKIN A.K., OZDOGAN M., KULACOGLU H. and AYDIN R.: "A novel material in seton treatment of fistula-in-ano," American Journal of Surgery, Vol. 193, No. 6, pp. 794-796, 2007.

11- VATANSEV C., ALABAZ O., TEKIN A., et al.: "A new seton type for the treatment of anal fistula," Digestive Diseases and Sciences, Vol. 52, No. 8, pp. 1920-1923, 2007.

12- MENTES B.B., OKTEMER S., TEZCANER T., AZIH C., LEVENTOGLU S. and OGUZ M.: "Elastic one-stage cutting seton for the treatment of high anal fistulas: Preliminary results", Techniques in Coloproctology, Vol. 8, No. 3, pp. 159-162, 2004

13- CIROCCHI R., SANTORO A., TRASTULLI S., et al.: "Meta-analysis of fibrin glue versus surgery for treatment of fistula-in-ano", Annali Italiani Di Chirurgia, Vol. 81, No. 5, pp. 349-356, 2010.

14- SHANWANI A., NOR A.M. and AMRI N.: "Ligation of the intersphincteric fistula tract (lift): A sphincter-saving technique for fistula-in-ano", Diseases of the Colon and Rectum, Vol. 53, No. 1, pp. 39-42, 2010.

15- ZBAR A.P., RAMESH J., BEER-GABEL M., SALAZAR R. and PESCATORI M.: "Conventional cutting vs. internal anal sphincter preserving seton for high trans-sphincteric fistula: A prospective randomized manometric and clinical trial", Techniques in Coloproctology, Vol. 7, No. 2, pp. 89-94, 2003. 


\section{علاج الناصور الشرجى المركب باستخدام سيتون الكابل}

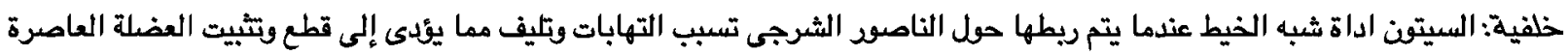

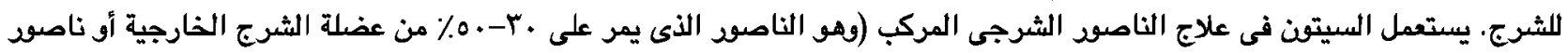
متشعب أو ناصور مرتجع أو ناصور في المرحي النوضى الذين يعانون من عدم تحكم فى البراز). الهدف من البحث: تحديد معدل حدوث عدم التحكم فى البراز ومعدل الانتكاسة فى المرضى الذين يعانفن من ناصود شرجى مركب والذين تم علاجهم بالسيتون الكابل فى مستشفى تعليمى مرجعى.

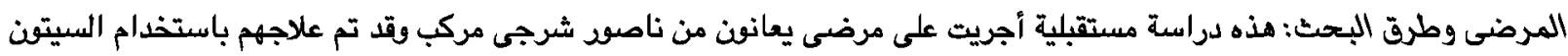

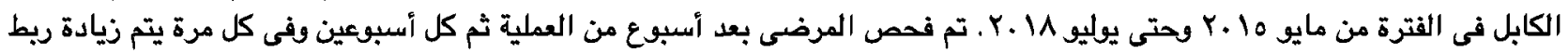
السيتون بدون مخدر وتقييم مدى نسبة التحكم فى البراز.

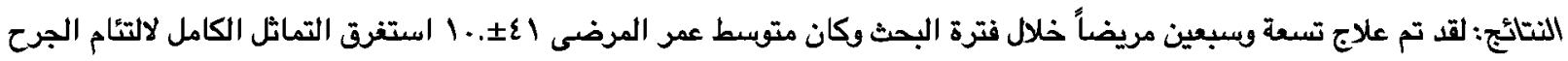

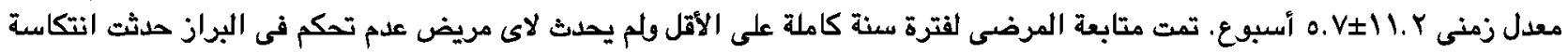

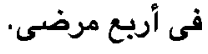
الاستتاج: أن استعمال السيتون الكابل طريقة آمنة وموفرة مادياً هع معدل خطورة أقل فى علاج الناصود الشرجى المركب ولذلك ينصح به فى علاج الناصود الشرجى المركب. 